https://doi.org/10.18485/kud_kiaz.2019.ch8

\begin{abstract}
Камал Абдуллаев
доктор филологических наук, профессор, действительный

член Национальной академии наук Азербайджана, Ректор Азербайджанского университета языков
\end{abstract}

\title{
ПРИНЦИПЫ МУЛЬТИКУЛЬТУРАЛЬНОЙ БЕЗОПАСНОСТИ В АЗЕРБАЙДЖАНЕ
}

\begin{abstract}
SUMMARY
The development of any multicultural society is associated with a number of problems and difficulties, since such a society is a single space in which representatives of different cultures, confessions coexist. In this regard, the problem of multicultural security and its principles become an important aspect of research. Of particular interest is the materialization of multicultural security in Azerbaijan.
\end{abstract}

Key words: multicultural security, state, multiculturalism, Azerbaijan.

Сформировавшиеся в историческом процессе этнокультурные многообразия (многокультурность, мультикультурализм) и образующие их основу этнокультурные ценности играют важную роль в развитии народов и государств. Но когда эти многообразия не регулируются государством или же регулируются неправильно, когда в стране не формируется соответствующая мультикультурная политика, возникают серьёзные проблемы, происходят конфликты. Поэтому правильное регулирование многообразия имеет большое значение для каждого поликультурного государства. 
К сожалению, сам мультикультурализм тоже не принёс одинаково положительных результатов, ожидаемых от него в разных странах. В каких странах, какие он дал результаты - прежде чем приступить к поискам ответа на этот вопрос, мы должны установить, что легло в основу этнического и религиозного многообразия той или иной страны?! Одни страны, минуя многообразие, пришли к точке соприкосновения с другими культурами как моноэтнические сообщества. В других же многообразие имеет исконный (первоначальный) характер. В первом случае привнесенным мультикультуральным ценностям нелегко было прижиться в стране с уже сложившимися нормами. Попытки привития новых ценностей в таких странах волей-неволей обретали искусственный характер. Поэтому, крах данной модели в некоторых странах Европы, например, в Великобритании, Франции, Германии, произошёл, как по субъективным, так и по преимущественно объективным на то причинам.

В ряде стран мира многообразие начинается с самых ранних периодов их истории. Разные народы, проживавшие на территории этих государств, начиная с древнейших времён, дошли до современности, формируя друг друга. Если не разграничить «первоначальное» и «позднее» многообразия, нам не удастся раскрыть тайну краха мультикультурализма в какой-либо отдельной стране современного мира и его торжества в какой-то другой стране.

Существующая в Азербайджане мультикультуральная атмосфера - сосуществование различных конфессий, этнических сообществ в условиях мира и дружбы - своими истоками уходит в древнейшие периоды нашей истории. «Первоначальное» многообразие, наблюдаемое на территории Азербайджана, - одно из редких в мире явлений, и оно, как было отмечено, резко отличается от «позднего» многообразия. Именно «первоначальное» многообразие сформировало сохранившуюся на территории Азербайджана модель системных отношений. И в результате этого 
именно в Азербайджане, в особенности в период независимости, приверженность и лояльность к многообразию, веками проявлявшиеся в творениях поэтов, писателей, учёных, смогли обрести новый, теперь уже политический лад. Неудивительно, что в то время, когда в ряде стран Запада, в той же Франции, Англии, Германии делались официальные заявления о крахе мультикультурализма как политической линии, в Азербайджанской Республике мультикультурализм становится государственной политикой. На начальном этапе государственной независимости Азербайджана великий лидер Гейдар Алиев для успешного развития Азербайджана избрал очень точную идеологическую цель. Он развил традицию многокультурности в Азербайджане и вывел её в качественно новую плоскость - политическую. Политика мультикультурализма, основа которой была заложена великим лидером, на современном этапе успешно развивается Президентом Ильхамом Алиевым.

Как отметил Президент Азербайджанской Республики Ильхам Алиев, мультикультурализм стал образом жизни нашего народа. Превращение мультикультурализма в образ жизни гражданского общества - высшая ступень его развития. На этой ступени утверждение общечеловеческих ценностей, таких чувств, как доброта, милосердие, сострадание, терпимость, обретают в обществе особые масштабы и особую значимость. Идеи мультикультурализма укрепляются в общественном сознании.

Несомненно, в сравнении со странами Западной Европы Азербайджан имеет относительно малый реальный опыт демократического развития. Но он богат духовным опытом. Из наших дастанов, сказок, образцов нашей классической литературы можно привести немало примеров, связанных с древними демократическими принципами. Можно долго говорить о толерантности в духовной жизни Азербайджана в течение всей его истории. Всё это, естественно, является доказательством тому, что мультикуль- 
туральный образ жизни был свойствен азербайджанскому обществу изначально.

Возникает вопрос: где, в каких странах потерпели неудачу мультикультуральные ценности? Это произошло там, где после завершения процесса духовного становления общества на новых миграционных волнах стали привноситься новые, до сей поры неведомые ему мультикультуральные ценности, чуждые ему воззрения. И уже сформировавшийся общественный, государственный организм не смог принять эту новую, искусственно прививаемую культуру.

В Азербайджане эти ценности с самого начала не имели искусственного характера. Изначально они имели естественное происхождение. В этом-то и суть вопроса. И мы методологически должны разграничивать понятия «первоначальное многообразие» и «позднее многообразие». Первоначальное многообразие в реальности не содержит в себе элемента миграции. Это сосуществование, совместное бытие многообразий с самого начала. Имея в виду именно это, Президент Азербайджана Ильхам Алиев указывает, что «традиции мультикультурализма в течение веков всегда существовали в Азербайджане. Просто, назывались они по-разному, но суть не менялась». Именно поэтому Азербайджан сумел противостоять проблемам, возникшим в европейских странах в области осуществления политики мультикультурализма.

$$
* * *
$$

Что такое мультикультуральная безопасность? Нам известны многие составляющие национальной безопасности государства - экономическая, транспортная, культурная, энергетическая, продовольственная и др. Каждая из них, и все они вместе взятые, являются важными для жизни государства сферами. В данную систему как целостный компонент безопасности можно также ввести мультикультуральную составляющую, которая выступает 
как неотъемлемая часть духовной, идеологической жизни. Так же, как страна обеспечивает свою энергетическую, экономическую, культурную безопасность, она должна обеспечивать и безопасность мультикультуральную.

Мультикультуральная безопасность включает в себя ряд принципов. Эти принципы обусловливают ситуацию, когда государство ощущает себя уверенным, справедливым, здоровым организмом, имеющим непрерывно и качественно обновляющуюся суть. Дух мультикультурализма, мультикультуральной безопасности заключается в том, чтобы в той или иной стране права и свободы каждого охранялись независимо от его расовой, национальной принадлежности, от его религии и языка, чтобы охрана и развитие культурных ценностей всех народов, этнических групп осуществлялись в равной мере. Если проблемы, возникающие в области обеспечения мультикультуральной безопасности общества, начнут обостряться, то это приведёт к противостояниям на этнической, религиозной, расовой почве. Наглядным тому примером является наблюдаемое в последнее время в ряде европейских стран усиление тенденций этнического и религиозного радикализма, национализма, ксенофобии, антисемитизма, исламофобии.

$$
* * *
$$

Что подразумевают принципы мультикультуральной безопасности? Президент Ильхам Алиев в одном из своих выступлений отметил, что в зарубежных странах его часто с удивлением спрашивают: что стоит в основе столь толерантного, дружественного отношения друг к другу руководителей различных конфессий в Азербайджане? В чём причина этого?

Признаемся, что для азербайджанца сама постановка этого вопроса звучит странно. Потому что современный азербайджанец ощущает эти отношения всей своей душой, всем своим существом. Он может и не знать этих причин. Но подобные отношения важны для нашей жиз- 
ни так же, как воздух, как вода. На этот вопрос, конечно, имеется и рациональный ответ. Наличие в Азербайджане такой среды связано с тем, что политическое руководство страны, глава государства проводит одинаковую политику в отношении ко всем конфессиям. Не ставит между ними каких-либо различий. Одинаковое политическое отношение, в свою очередь, обусловливает толерантное отношение конфессий друг к другу и каждой из них - к государству. Итак, мы пришли к первому основному выводу: один из основных и наиболее важных принципов мультикультуральной безопасности заключается в создании механизма равного политического отношения к разным конфессиям внутри страны.

Другой принцип мультикультуральной безопасности предполагает наличие государственной заботы, направленной на сохранение имеющегося в стране национального многообразия.

Азербайджан - это страна, где в условиях мира, дружбы, братства, разделяя радости и невзгоды друг друга, живут представители разных народов. Эту территорию превратили в общую свою родину современные наследники древней Кавказской Албании - удины, аварцы, лезгины, а также евреи, талыши, русские, грузины, курды, а в недавнем прошлом - ещё и немцы. Сегодня те армяне, которые не приемлют абсурдных притязаний сепаратистов, тоже считают эту землю своей родиной. Хиналугцы, джекцы, каждый из которых населяет всего одно село, язык и этническая идентичность которых кроме своих сёл нигде больше не встречается, также принадлежат Азербайджану. Языковое и культурное богатство всех этих народов наше государство считает своим богатством, своим достоянием. Великий лидер Гейдар Алиев говорил: «Государство, чем больше народов оно объединяет, тем богаче, потому что каждый из них вносит свой вклад в общемировую культуру и цивилизацию».

Сложившееся в Азербайджане новое, демократичное сообщество сегодня активно участвует в строительстве независимого государства. Национальное многообразие 
не мешает живущим в нём людям чувствовать себя азербайджанцами. Каждый народ может говорить на своём родном языке, может писать на нём, удовлетворять свои культурные потребности. В статье 44 нашей Конституции «Право на национальную принадлежность» указывается: «Каждый обладает правом сохранять свою национальную принадлежность. Никто не может быть принужден изменить свою национальную принадлежность».

Представителей проживающих в стране различных народов сегодня можно увидеть во всех областях жизни независимого Азербайджана - в политике, экономике, образовании, спорте, духовной жизни, словом, везде. Ещё один важный принцип мультикультуральной безопасности формируется благодаря поддержке, оказываемой государством и обществом культурному многообразию в стране.

Таким образом, общеазербайджанский культурный контекст стал для населяющих нашу страну народов, общим духовным пространством. Сегодня эта политическая линия - одна из приоритетных для Азербайджанского государства.

$$
* * *
$$

Ещё одним важным условием сохранения культурного многообразия является то, что, наряду с государством, этим делом должны заниматься гражданское общество и поддерживающие его деятельность структуры. С этой точки зрения можно, в первую очередь, назвать Фонд Гейдара Алиева, который претворяет в жизнь грандиозные проекты. Реальную работу в этом направлении проводят Совет государственной поддержки неправительственных организаций при Президенте Азербайджанской Республики, Фонд государственной поддержки развития средств массовой информации при Президенте Азербайджанской Республики, недавно созданный Президентом Азербайджана Бакинский международный центр мультикультурализма. 


$$
* * *
$$

Проведённый на примере Азербайджана анализ мультикультуральной безопасности показывает, что при целенаправленном соблюдении её принципов не только раскрывается в полной мере внутренний потенциал страны, залегающие в глубинных его пластах богатства, но и обогащается имидж страны дополнительными позитивными штрихами. Ещё один грандиозный тому пример первые Европейские игры, которые ещё раз подтвердили, что гражданину Азербайджана чужда самоизоляция во всех её проявлениях, он смотрит на все народы и нации в мире как на своих. Есть одна семиотическая оппозиция, которую многие народы всё ещё не могут преодолеть: оппозиция «свой-чужой». Для наших соотечественников эта оппозиция ещё в средние века начала терять свой смысл. Сегодня эта оппозиция имеет предельно «мягкую» форму.

Место мультикультуральных ценностей и в литератуpe, и в психологии, и в отношении к миру, и в современных политических воззрениях очевидно. Именно поэтому сегодня «Азербайджанский мультикультурализм» как учебный предмет привлекает европейские университеты. Можно отметить, что в ряде университетов уже началось преподавание названного предмета. Сегодня университеты Литвы, Грузии, России, Болгарии, Беларуси, Италии, Чехии, Японии, Португалии, Индонезии проявляют интерес к Азербайджану, предлагая своим студентам курс «Азербайджанский мультикультурализм». Следует подчеркнуть, что одновременно началось преподавание этого предмета также в университетах Азербайджана. Количество таких университетов, как зарубежных, так и отечественных, будет возрастать с каждым семестром. Само преподавание этого предмета в азербайджанских и зарубежных университетах является ещё одним из принципов мультикультуральной безопасности.

Можно заключить, что принципы мультикультуральной безопасности для небольших, но имеющих глубокие 
корни и историю стран, каким является и Азербайджан, столь же важны и необходимы, как и принципы других доктрин безопасности. Утверждение перечисленных здесь принципов в Азербайджане стало возможным благодаря совместным усилиям и совместному труду граждан нашей страны. Предотвращение сторонних идеологических вмешательств, сведение к минимуму провокационного характера тенденций зависит, в том числе, и от осуществления данных принципов. По мере приближения к точно указанной великим лидером идеологической цели мир адекватно узнаёт и с нарастающим интересом продолжает изучать и оценивать нас. А это, в конечном итоге, означает усиление лояльного отношения к Азербайджану в разных частях земли.

\section{РЕЗЮМЕ}

Развитие любого мультикультурального общества сопряжено с рядом проблем и сложностей, поскольку такое общество - единое пространство, в котором сосуществуют представители различных культур,конфессий. В этой связи проблема обеспечения мультикультуральной безопасности и ее принципы, становятся важным аспектом исследований. Особый интерес представляет осуществление мультикультуральной безопасности в Азербайджане.

Ключевые слова: мультикультуральная безопасность, государство, мультикультурализм, Азербайджан. 